\title{
CHILDREN AND TECHNOLOGY: PREOCCUPATIONS, PRACTICES AND PARTICIPATION IN EARLY CHILDHOOD EDUCATION
}

\author{
M. Figueiredo', V. Alves ${ }^{2}$ \\ ${ }^{1}$ Polytechnic of Viseu, School of Education of Viseu and CI\&DEI (PORTUGAL) \\ ${ }^{2}$ Polytechnic of Viseu, School of Technology and Management of Viseu and CiSED \\ (PORTUGAL)
}

\begin{abstract}
Children live in a complex world where technology plays different roles and influences several spheres of their existence. Research about the presence and educational impact of technology in childhood reveals several challenges. A particular challenge is connected to the need for a high-quality pedagogy regarding technology in Early Childhood Education. This paper contributes to that discussion from a Portuguese perspective. The pedagogical and curricular framework for Early Childhood Education in Portugal supports a significant use of technology in the daily practice and in children's play. In this context, the paper explores three main axes to understand a high-quality pedagogy for using technology with children in educational contexts: technology presented as a tool with socially authentic practices; technology as supporting multiple languages that are relevant for children to understand the world around them; and technology as an arena for children's participation. Each axis is supported by the analysis of specific projects developed locally at the School of Education. The projects were selected for highlighting tenets of each axis. Each axis is also connected to the three content areas of the Portuguese Curricular Guidelines and to dimensions of a sociocultural pedagogy for Early Childhood Education.
\end{abstract}

Keywords: Early childhood education, technology, participation, play, pedagogy.

\section{INTRODUCTION}

Early Childhood Education has a strong tradition of pedagogy, acknowledged as relevant not only for young children but also for other levels of the educational system. As Resnick puts it, "If this learning approach has been so successful in kindergarten, why hasn't it been applied in other parts of the educational system?" [1, p. 2]. Still, for many years, research has noted the unbalanced relationship between a society interlaced with technology in virtually all aspects of modern day life and the lack of technology in Early Childhood settings that "still lag substantively behind in embracing the potential of a vast cadre of new and powerful learning tools" [2, p. 339]. Families also seem challenged when managing screen-time and the digital activities of children [3]. On the other hand, over the past two decades, there has been a surge in research about the relationship between children, young people and the media [4].

The take-up of digital technologies by children led to question children's rights in connection to the Internet and technology. Children's specific digital needs and vulnerabilities have been acknowledged in policy documents and there is an interesting and relevant proposal by researchers Livingstone and O'Neill [5] to categorize children's rights in the digital sphere against the three pillars of the Convention on the Rights of the Child [6]:

Pillar I - Protection

Children's rights to protection and privacy (Articles 8, 16, 17e, 19, 34, 36)

Pillar II - Provision

The right of children to access equally the digital world, the right to play, the right to information and education (Articles 17, 28, 29, 31)

Pillar III - Participation

The right to freedom of choice and speech (Articles 3, 12, 13, 15).

Questions regarding social justice and children's rights around access to interactive technologies have always been on the research and policy agendas. The COVID-19 pandemic and resulting physical and social isolation has foregrounded new digital divides with widely varying experiences around the impact 
of physical and social isolation on families [7]. The historical discourses around children and technologies suggest that a critical-optimistic approach [8], in conjunction with attention to discourses about childhoods in contemporaneity [9], is needed to address the risks and opportunities at stake.

The particular challenge for educators and researchers in the area of ECE has been laid out by Kewalramani, Arnott and Dardanou [10]: there is evidence of the pros and cons related to the integration of technology in early childhood education and the subsequent influences on children's cognitive learning and affective engagement with their everyday world, but an effort is still needed in relation to high-quality pedagogies with technologies. This paper contributes to this challenge by discussing projects developed in ECE settings in terms of alignment with the founding principles of Early Childhood Pedagogy.

\section{THE PORTUGUESE CONTEXT}

Portuguese studies report that technology is strongly involved in the day-to-day of families, with leisure and "baby-sitting" uses more than creative or educational ones [3], [11], [12]. The mobile phone and the television are the prevalent screens, followed by tablets and laptops. The TV is what is more common in the daily life of children, mostly for watching channels targeted at children. This TV presence is dominant and intense, acting as babysitter and a distraction or pacifier for allowing parents to dress or feed the children, or even for falling asleep. Internet access is more prevalent in older children than in ECE children and its use is connected to games, cartoons, and short movies [11].

The curricular framework for ECE in Portugal considers technology in different ways. Since 2016, the Portuguese Curricular Guidelines for Pre-School Education [13] have explicit mentions of technology, particularly in the Knowledge of the World area under "Technological World and Use of Technologies". The document assumes children need to learn about, use and gain a critical understanding of the several technological resources existing in the world around them, both for leisure (technological toys, computers, tablets, smartphones, television, etc.), as well as in their daily lives (electric mixer, heater, hairdryer, bar codes, flashlights, etc.). Children's use of a computer is also suggested either in the school, or elsewhere in the community. It's indicated that this use should be connected to collecting information, communicating, organising, processing data, etc. Research shows that teachers and children, when talking about children playing with computers, usually refer to children using computers during playtime performing a series of different activities (associated with different types of software, including computer games) [14], [15]. The same holds true about other technologies, but playing with technology is not as restrictive and includes everyday technological objects and toys [16], [17] that can be used in play as cultural tools [18]. Playing with technology as a way of building meaning about technology in society, therefore, includes playing beyond the use of that technology, incorporating it in interpretative reproductions [17], [19]. The curricular framework acknowledges this perspective.

Finally, there is no mention of code or coding in the framework that assumes a more holistic approach to technology as part of the daily and future life of children [20]. In summary, the pedagogical and curricular framework for Early Childhood Education in Portugal supports a significant use of technology in daily practice and in children's play.

\section{A PEDAGOGICAL APPROACH}

Early Childhood Pedagogy is founded on children's rights and includes two main dimensions: interactions between children and adult and the organization of the context where those interactions take place [21]. This context is physical, including the space and the materials, but also relational and functional. In terms of interactions, listening to children about their experiences and interests and opportunities for rich and meaningful play are important [22]. The first allows for activities that are presented and directed by the adult to be relevant for the children and promote meaningful learning. The second is an important tenet of Early Childhood Pedagogy as play is a crucial way of learning for children. The critical perspective that is desired by the curricular framework requires a pedagogical approach based on the foundations of the same framework: productive relationships with families, valuing of play and children's participation. These are also aligned with what the research on technology in ECE has highlighted.

A synthesis of the position statements, reports, research reviews, guidelines, and recommendations about technology in ECE released in the last decade identifies strong agreement on a set of 10 foundational elements necessary for successful technology integration with young children [23]. From those, we highlight: 
a) Relationships-A child's use of media and technology should invite and enhance interactions and strengthen relationships with peers, siblings, and parents.

b) Social and emotional learning-Technology should be used in ways that support positive social interactions, mindfulness, creativity, and a sense of initiative.

c) Early childhood essentials-Technology use should not displace or replace imaginative play, outdoor play and nature, creativity, curiosity and wonder, solitary and shared experiences, or using tools for inquiry, problem-solving, and exploring the world.

d) Adult habits-As the primary role models for technology and media use, adults should be aware of and set limits on their own technology and media use when children are present and focus on children having well-rounded experiences, including moderate, healthy media use.

A primary recommendation is that technology is part of the pedagogical approach and therefore is incorporated with other elements and is planned and reflected with the same principles and conceptions that guide practice.

In this context, the paper explores three main axes to understand a high-quality pedagogy for using technology with children in educational contexts: technology presented as a tool with socially authentic practices; technology as supporting multiple languages that are relevant for children to understand the world around them; and technology as an arena for children's participation. Each axis is supported the analysis of specific projects developed locally at the School of Education. The projects were selected for highlighting tenets of each axis. Each axis is also connected to the three content areas of the Portuguese Curricular Guidelines and to dimensions of a sociocultural pedagogy for Early Childhood Education.

\subsection{Technology as a Tool with Socially Authentic Practices}

The idea that school cannot be dissociated from life is easily associated with Dewey [24] and is very present in Early Childhood Pedagogy. Welcoming authentic social processes of daily life, the sciences and arts and culture is, for example, a strong tenet for the pedagogical grammar of the Movimento da Escola Moderna [25], [26]. The appropriation of this concept into technological relevant practices in ECE has been developed by Amante [18], [27]. The computer, and any technology, have a role and uses outside the school, in different spheres of society. In the pedagogical practices of ECE those roles and uses are seen as important. This means that instead of educational software and games, or toy versions, the computer, the mobile, the tablet, and any other technology, should be used and associated with their socially authentic practices. This is valid for the tool and the practices connected to it. A second dimension of this axis is that adults in ECE contexts act as models of those uses and practices. As with language, the relationship that the adults have with technology and the way they explicitly consider their role as models will impact greatly the children's learning. Finally, technology as a tool with socially authentic practices means looking at children as users of technology in the present, not as being prepared to be users in their future. Respecting their ideas and preferences is important.

This set of ideas connects with the content area Knowledge of the World and its perspective on the technological world. It also connects with the area Expression and Communication since technology is a means of communication that uses different languages and codes.

Four pedagogical elements make this axis more specific: the presence of technology in the classroom needs to be intentionally considered and decided, as part of the pedagogical organization of the space and materials; children's play can be enriched with technological or digital materials and, when observing play, the uses and mentions of technology need to be valued by the teachers; sharing and debating contents accessed through technology (including TV) helps children make sense of what they see and establish connections with several other experiences; and talking with the families about questions regarding screens, digital and technology in their children's lives in a positive and productive way is very relevant.

\subsection{1 "Let's repair ICT" - a Play Area with Real Tools}

A study was developed in the context of the Master's Degree in Early Childhood and Primary Education about the meanings children attribute to technology in the context of creating and exploring a play center [17]. The play center was created by the children through a project approach that researched about technology in daily life. The planning was flexible and the project resulted in the involvement and participation of children in the reconstruction of the educational space of the activity room to create the "repair 
ICT" play center that had several real devices (laptops, PSP, tablets, mobile phones, flash drives) for make-believe situations.

With the creation of the play center, it was intended that children explored technology in various aspects: the play center afforded the role of users but also repair specialists, knowing how they work "from the inside". The results suggest that the diversity of electronic devices and the possibilities of manipulation and free exploration in the context of playing allowed children to develop a diverse relationship with technology that included agency and specific knowledge related to the components and technical and social usage of the devices.

In this case, real ICT was brought to ECE setting for children to play with, interpretatively reproducing their experiences with them. A technical repair specialist came to classroom, again with real tools, and showed how to open and repair technological devices. Children's play was valued and the basis for decision-making that involved and impacted children. Children saw themselves as users but also as repairers of technology.

\subsection{Technology as Supporting Multiple Languages}

Children, as human beings, are complex and fluent in different languages and ways of expressing and understanding the inner and outer world; in Mallaguzi's words, children have a hundred languages [28]. Technology as a tool for communication has an enormous potential to support children's expression and to be presented as a tool in the sense of extending human capabilities. Both adults and children can use different languages and this axis maintains that different languages should be listened to in ECE settings. With that inclusive approach, the educational space and community are amplified. The Internet allows communication with many actors and entities and access to diverse ways of expressing knowledge, emotions, humanity.

This set of ideas connects with the content area Personal and Social Development in terms of contributing to identity and respect for diversity. It also connects with the area Expression and Communication by valuing different languages and supporting access to cultures.

Four pedagogical elements make this axis more specific: the technological tools available in the classroom or setting need to be explicitly diverse, to cover the range of means of expression that are offered by technology; again, children's play can be enriched and observed as a way of listening to the ideas and experiences brought by the children to the group; the spaces where learning happens need to extend from the classroom to other spaces in the setting and to the outdoor; and families and communities have a strong role to play in making this axis a tenet for a high-quality pedagogy.

\subsubsection{Children and Parents Playing with Technology in the City}

A study was developed in the context of the Master's Degree in Early Childhood and Primary Education to offer meaningful experiences of technology use in the city for children and parents [29]. The city was regarded as a set of outdoor spaces where play between children and parents (and other family members) can happen. The study wanted to challenge the idea that technology hinders both children's play and quality time for families. Three challenges were presented to families and children of one ECE setting. The first suggested that the family found the three TOMI in the city of Viseu and took their pictures there. TOMI is an interactive urban solution present in many cities of the world that that delivers information for users and has the option of taking selfies that are sent to the users' email by the device. It was also suggested that family members tried to guess how many steps the walk would entail and then used a pedometer on the mobile phone for checking the accuracy of their guesses. Finding the three TOMI could also entail using a map app. The second challenge was connected to a tree in the city's park that was older than the first photograph ever taken. Families were challenged to find that tree (The Alvarinho Oak) and photograph it with the mobile phone. For celebrating the old age of the tree, it was suggested that with an app, the photo was edited to look aged. The third challenge was to create a challenge to share with other families.

This project took technology into the urban outdoor space, connecting it with physical activity and nature - and play!. It involved families and different tools, as well as allowing for authorship from the users. It also presented parents and families as users of technology in ways that can be shared with children and that are about visual language. 


\subsection{Technology as an Arena for Children's Participation}

This axis combines a central tenet of Early Childhood Pedagogy with relevant uses of technology. Children are seen as subjects of the educational process, with agency, competent, and right-claiming subjects [9], [13], [30]. Technology in ECE is one of the areas where children can have a voice and make decisions. It can also be a support for decision making. The connection between technology and participation entails understanding participation as a right expressed in articles 12 and 13 of the CDC [6]. It brings the responsibility of listening to children as they have the right to be heard and having their opinions considered, including in ECE settings [31]. Considering some of the suggestions regarding ECE settings [32], the connection to a high-quality pedagogy becomes clearer:

- Listen to children: with a sensitive attitude, promote an environment in which children feel that their contributions are valued and considered; provide daily opportunities for children to share their experiences, in group activities; create specific situations that children can participate in; ask what they would like to do or what materials they would like to use; allow children the freedom and confidence to talk about their needs, interests and preferences, giving them space to take initiative.

- Include and hold the child accountable: include children in planning and be available to change plans to fit the interests revealed by the children; include children in negotiating rules and procedures; give responsibility for day-to-day tasks included in the setting that are relevant for the collective; involve children in fulfilling and evaluating established goals, by filling in tables or holding assemblies.

- Encourage the child's choice and initiative: allow children to choose when and with whom they want to play, giving them freedom and autonomy; respect each child's rhythms and preferences; create opportunities for children to propose activities and games to adults, allowing the emergence of new projects based on their experiences and interests; make it easier for the child to access the different materials and toys in the room, so they can explore freely.

This set of ideas connects with the content area Personal and Social Development in terms of making choices and managing emotions. It also connects with the area Expression and Communication by valuing communication and negotiation, required for decision making.

Two generic pedagogical elements make this axis more specific: observing and talking about children's play which is itself an arena for agency and participation; and the value of a pedagogy of listening [33], as young children find ways to communicate without words, and a pedagogy-in-participation [34].

\subsubsection{Children Learn about Changing Technology}

A study was developed in the context of the Master's Degree in Early Childhood and Primary Education about the different uses and contributions technology played in the context of a project approach, developed with children in an Early Childhood Education center, about how things have changed since our grandparents' time [35]. The project approach started with a close observation of children's interests about how things used to be. From that starting point, children's in-depth investigation of the topic "change" was developed. Throughout the process, the teacher's role was to support children through their inquiry, preparing in advance, and analyzing the educational and learning potential of the experience. In this instance, particular attention was given to the uses of technology in the different stages of a project approach. The analysis focused on how technology was relevant for that work and resulted in five categories: registering children's ideas, searching information, documenting the process, organizing knowledge and tasks, and presenting the work and the results to others. Across the different categories, instances of decision-making are present. Children participated in the planning, gave suggestions, decided what to search about, in what order, and were agents in gathering the materials used for the investigations.

A project approach tends to create ample space for children's participation. In this case, the role of technology is highlighted: by making decisions visible, it supported children in their negotiations and decisions. Children also made decisions about digital resources and technologies they wanted to use and learn about.

\subsubsection{Algolittle}

Algolittle is an EU-funded project, with partners from Portugal, Italy, Turkey and Slovenia, in search of ways to integrate Algorithmic Thinking skills into preschool education [20]. Algorithmic Thinking stems from the concept of an algorithm, which refers to solving a problem by developing a set of steps taken 
in a sequence to achieve the desired outcome In ECE, Algorithmic Thinking involves problem-solving skills and particular dispositions, such as confidence and persistence when confronting particular problems. In the project, children are perceived as competent problem-solvers who can be trusted to conceive steps to be taken to approach a situation. The team is invested in observing play as presenting problematic situations that children are capable of solving. This puts the focus on children's agency and participation, instead of on following steps and procedures presented by the adults.

\section{CONCLUSIONS}

Valuing play, participation and the promotion of connections with families and communities, in socially authentic practices, proved relevant in the projects and studies reported in this paper. With that approach, technologies become complementary resources, rather than competing artifacts which, some consider, may threaten early childhood ways of being [10]. Some risks are still present. One is the overvaluing of individual decisions by children, which is associated with the concept of users and consumers, when the focus should be on decisions leading to democratic practices, considering the collective and the consequences of choices. The second one refers to the neglecting of children's ways of expressing themselves in terms of preferences, interests, problem-solving and decisions: play has an important role here. If teachers value play and know how to read it for knowing the children, for listening, a higherquality pedagogy can be achieved, based both on interactions between children and adult and on the organization of the context where those interactions take place [21].

\section{ACKNOWLEDGMENTS}

This work was funded by National Funds through the FCT-Foundation for Science and Technology, I.P., within the scope of the project ref: UIDB/05507/2020. Furthermore, we would like to thank the Centre for Studies in Education and Innovation (CI\&DEI) and the Polytechnic of Viseu for their support.

This work was supported by the European Commission through Erasmus+ funding as "Algorithmic Thinking Skills through Play-Based Learning for Future's Code Literates", 2020-1-TR01-KA203-092333.

\section{REFERENCES}

[1] M. Resnick, «All I really need to know (about creative thinking) I learned (by studying how children learn) in kindergarten», em Proceedings of the 2007 Conference on Creativity and Cognition, Washington DC, USA, 2007, pp. 1-6.

[2] H. P. Parette, A. C. Quesenberry, e C. Blum, «Missing the Boat with Technology Usage in Early Childhood Settings: A 21st Century View of Developmentally Appropriate Practice», Early Childhood Education Journal, vol. 37, n. 5, pp. 335-343, 2010.

[3] R. Brito e P. Dias, «"Which apps are good for my children?": How the parents of young children select apps», International Journal of Child-Computer Interaction, vol. 26, p. 100188, 2020, doi: 10.1016/j.ijcci.2020.100188.

[4] S. Pereira, C. Ponte, e N. Elias, "Crianças, jovens e media: perspetivas atuais», revistacomsoc, vol. 37, pp. 9-18, 2020, doi: 10.17231/comsoc.37(2020).2687.

[5] S. Livingstone e B. O'Neill, «Children's Rights Online: Challenges, Dilemmas and Emerging Directions», em Minding Minors Wandering the Web: Regulating Online Child Safety, vol. 24, S. van der Hof, B. van den Berg, e B. Schermer, Eds. The Hague: T.M.C. Asser Press, 2014, pp. 19-38. doi: 10.1007/978-94-6265-005-3_2.

[6] United Nations, «Convention on the Rights of the Child». United Nations, 1989.

[7] A. N. Antle e C. Frauenberger, "Child-Computer Interaction in times of a pandemic», International Journal of Child-Computer Interaction, vol. 26, p. 100201, 2020, doi: 10.1016/j.jicci.2020.100201.

[8] C. Trueltzsch-Wijnen e C. Aliagas, «New tech new fears? A look at historical discourses around children and technologies», em The Internet of Toys: A Report on Media and Social Discourses around Young Children and loToys, G. Mascheroni e D. Holloway, Eds. DigiLitEY, 2017, pp. 12-14.

[9] C. Tomás, «Para além de uma visão dominante sobre as crianças pequenas: gramáticas críticas na educação de infância», Revista Humanidades \& Inovação, vol. 4, n. 1, pp. 13-20, 2017. 
[10] S. Kewalramani, L. Arnott, e M. Dardanou, «Technology-integrated pedagogical practices: a look into evidence-based teaching and coherent learning for young children», European Early Childhood Education Research Journal, vol. 28, n. 2, pp. 163-166, 2020, doi: 10.1080/1350293X.2020.1735739.

[11] C. Ponte, A. J. Simões, S. Batista, A. Jorge, e T. Castro, «Crescendo entre ecrãs: usos de meios eletrónicos por crianças (3-8 Anos)», ERC - Entidade Reguladora para a Comunicação Social, 2017.

[12] C. Ponte e C. Martins, «BOOM DIGITAL? Crianças (3-8 anos) e ecrãs», ERC - Entidade Reguladora para a Comunicação Social, 2018.

[13] Ministério da Educação, Orientações curriculares para a educação pré-escolar[Curricular Guidelines for Pre-School Education]. Lisbon: Ministério da Educação, 2016.

[14] L. Plowman e C. Stephen, "Children, play, and computers in pre-school education», $\mathrm{Br} J$ Educ Technol, vol. 36, n. 2, pp. 145-157, 2005, doi: 10.1111/j.1467-8535.2005.00449.x.

[15] J. Howard, G. E. Miles, e L. Rees-Davies, «Computer use within a play-based early years curriculum», International Journal of Early Years Education, vol. 20, n. 2, pp. 175-189, 2012, doi: 10.1080/09669760.2012.715241.

[16] K. Nikolopoulou e V. Gialamas, «ICT and play in preschool: early childhood teachers' beliefs and confidence», International Journal of Early Years Education, vol. 23, n. 4, pp. 409-425, 2015, doi: 10.1080/09669760.2015.1078727.

[17] M. P. Figueiredo, S. Santos, e B. Rego, «Playing with technology in Early Childhood Education: creation of a play center», em EduLearn 2021 Proceedings, 2021.

[18] L. Amante e Á. Faria, «Sentidos(s) emergente(s) das tecnologias digitais no jardim de infância», em Ensinar e aprender online com tecnologias digitais: abordagens teóricas e metodológicas, J. A. Moreira e A. Monteiro, Eds. Porto: Porto Editora, 2012, pp. 45-62.

[19] W. A. Corsaro, «Interpretive reproduction in children's role play», Childhood, vol. 1, n. 2, pp. 64-74, 1993, doi: $10.1177 / 090756829300100202$.

[20] M. P. Figueiredo et al., «Algorithmic Thinking in Early Childhood Education: Opportunities and Supports in the Portuguese Context», em EduLearn 2021 Proceedings, 2021, pp. 9339-9348.

[21] M. P. Figueiredo, H. Gomes, e C. Rodrigues, «Mathematical pedagogical content knowledge in Early Childhood Education: tales from the 'great unknown' in teacher education in Portugal», European Early Childhood Education Research Journal, vol. 26, n. 4, pp. 535-546, 2018, doi: 10.1080/1350293X.2018.1487164.

[22] M. P. Figueiredo, «Estudos no âmbito da Pedagogia de Infância», em Olhares sobre a Educação: em torno da formação de professores, L. Menezes, A. Cardoso, B. Rego, J. P. Balula, M. Figueiredo, e S. Felizardo, Eds. Viseu: Escola Superior de Educação de Viseu, 2017, pp. 178-181.

[23] C. D. R. Schomburg, «Technology and Interactive Media in Early Childhood Programs: What We've Learned from Five Years of Research, Policy, and Practice», Young Children, vol. 72, n. 4, 2017.

[24] J. Dewey, A Escola e a Sociedade e a Criança e o Currículo. Lisboa: Relógio D’ Água (original publicado em 1902), 2002.

[25] S. Niza, «O modelo curricular da educação pré-escolar da Escola Moderna Portuguesa», em Modelos Curriculares para a Educação de Infância, 2. ${ }^{a}$ ed., J. Oliveira-Formosinho, Ed. Porto: Porto Editora, 1998, pp. 137-159.

[26] M. A. Folque, O aprender a aprender no pré-escolar. O modelo pedagógico do movimento da escola moderna. Lisboa: Fundação Calouste Gulbenkian, 2012.

[27] L. Amante, «Explorando as novas tecnologias em contexto de educação pré-escolar: a atividade de escrita», Análise Psicológica, vol. 22, pp. 139-154, 2004.

[28] L. Malaguzzi, «História, ideias e filosofia básica», em As cem linguagens da criança. A abordagem de Reggio Emilia na educação da primeira infância, vol. 1, C. Edwards, L. Gandini, e G. Forman, Eds. Penso, 2016, pp. 59-104. 
[29] M. Loureiro, M. P. Figueiredo, e B. Rego, «Famílias a brincar com as TIC "lá fora": um projeto de envolvimento da família para promoção de uma utilização das TIC associada ao brincar e ao espaço», em Livro de resumos: Olhares sobre a Educação, L. Menezes, M. P. Figueiredo, B. Rego, J. P. Balula, S. Felizardo, e A. Cardoso, Eds. Viseu: Escola Superior de Educação de Viseu, 2018, pp. 29-31.

[30] T. Abebe, «Reconceptualising Children's Agency as Continuum and Interdependence», Social Sciences, vol. 8, n. 3, p. 81, 2019, doi: 10.3390/socsci8030081.

[31] L. Lopes, N. Correia, e C. Aguiar, «Implementação do direito de participação das crianças em contexto de jardim de infância: As perceções dos educadores», RPE, vol. 29, n. 2, p. 81, 2016, doi: 10.21814/rpe.6560.

[32] N. Correia, «"Os meninos podem escolher o que querem fazer": o direito de participação em salas de jardim de infância», PrimeirosAnos.pt, Mar. 10, 2018. https://primeirosanos.iscteiul.pt/2018/10/03/os-meninos-podem-escolher-o-que-querem-fazer-o-direito-de-participacao-emsalas-de-jardim-de-infancia/

[33] C. Rinaldi, In dialogue with Reggio Emilia: listening, researching and learning. Nova lorque: Routledge, 2006.

[34] J. Oliveira-Formosinho e J. Formosinho, Pedagogy-in-participation: Childhood Association educational perspective. Porto: Porto Editora e CESC/UM, 2012.

[35] M. P. Figueiredo, C. Gomez, e M. C. Gomes, «The Relevance of Technology for a Project Approach in Early Childhood Education: Learning about Change with our Grandparents», present at ICERI 2021, 2021. 